\title{
CONTROL OF BRUCELLA ORGANISMS DURING MANUFACTURING OF ACID CHEESE USING SOME ORGANIC ACIDS
}

\author{
KHALED, M. EL-KHAWAS ${ }^{*}$ and ESSAM, M. ELBAUOMY** \\ * First researcher Food Hygiene Department, Animal Health Research Institute, Agriculture Research Center, Dokki, Giza \\ ** Chief researcher, Brucella Department, Animal Health Research Institute, Agriculture Research Center, Dokki, Giza
}

Email: kkhwas@yahoo.com

Assiut University web-site: $\underline{\text { www.aun.edu.eg }}$

\section{ABSTRACT}

Received at: 8/8/2015

Accepted: 13/9/2015
Kariesh cheese is a highly nutritive soft acid cheese made from naturally fermented skimmed milk, mainly manufactured at home by small holders and sold at local markets. Due to unhygienic condition during manufacturing and low quality raw milk, many outbreaks of human brucellosis were reported. This study was done to evaluate the use of acetic and citric acids, as natural organic acids, to produce kariesh cheese instead of the traditional method to control Brucella infection. Sensory evaluation revealed that all treatments didn't differ $(\mathrm{P}>0.05)$ than control except $2 \%$ citric acid which characterized to a little extent by lemon flavor, crudeness body and texture and less whiter color than other treatments. B. meletensis strains didn't affected by acetic $(1 \%)$ or citric $(1.5 \%)$ acids, but both of them were completely inhibited by acetic (1.5\%), or have $4 \log$ reduction by citric (2\%) acids. For B. abortus the field and S19 strains were completely inhibited by $1 \%$ acetic acid, but citric acid $2 \%$ significantly $(\mathrm{P}<0.05)$ reduced the count of $\mathrm{S} 19$ and 544 strains by 4.46 and $3.32 \mathrm{log} \mathrm{cfu} / \mathrm{g}$, respectively. These results suggested that treatment of raw skimmed milk with acetic acid $1.5 \%$ or citric acid $2 \%$ is a good alternative for production of hygienic kariesh cheese to control brucellosis in human.

Key words: Kariesh cheese; acid cheese; organic acids; brucellosis; Brucella strains.

\section{INTRODUCTION}

Kariesh cheese is a soft acid cheese commonly made and consumed in Egypt. This cheese is an excellent source of protein, amino acids, calcium, phosphorus, vitamins and many micronutrients. It is an acid coagulated fresh cheese, made from skimmed milk (cow milk, buffalo milk or buttermilk from sour cream) with soft composition, white curd and slightly salty (Francois et al., 2004). Environmental conditions prevailing during processing and storage, combined with the composition of the cheese often, which reduces considerably its quality (Reps et al., 2002). As this cheese is mainly manufactured at home by small holders and sold at local markets, so it is exposed to contamination with several types of microorganisms. All microbiological quality parameters indicated low milk quality just before the milk is transferred into cheese factories. These results suggest that milk is heavily contaminated right from the farm level so kariesh cheese is unhygienically produced and pose public health risks (Hofi, 2011).

According to Center for Disease Control (CDC), important factors in reported cheese-associated outbreaks were manufacturing cheese with raw or improperly pasteurized milk and post-pasteurization contamination (Altekruse et al., 1998). Raw or inadequately pasteurized milk from infected animals and cheese made with such milk are a frequent vehicle for human brucellosis infection (Lusk, et al., 2013). Incidence of $B$. melitensis isolated from fresh cheese samples made from non boiled or nonpasteurized ewes' milk vary from area to other. Ongor et al. (2006) isolated B. melitensis from $5 \%$ of the samples, meanwhile Alim and Tomul (2005) isolated it from $8 \%$ of the samples and Kasimoglu (2002) isolated it from $14.2 \%$ of ewes' milk cheese samples at the level of 1.5-4 log MPN/g.

Brucellosis is a widespread zoonosis which is transmitted to man through direct contact with infected animals or through consumption of contaminated raw animal products, especially nonboiled or non-pasteurized milk and milk products such as cheese, cream and butter (Palmer et al., 1998; Alim and Tomul, 2005 and Seleem et al., 2010). Therefore, in countries where eradication of the disease in animals is not feasible, prevention of human brucellosis is primarily based on control of animal brucellosis, food-safety measures and raising the awareness of people on the impact of the disease on public health. Presenting complaints were variable, but a constant feature was persistent fevers that frequently were present for months. Evidence of liver cell dysfunction was present and diffuse 
hepatitis with focal necrosis (Young, and Suvannoparrat, 1975). Consumption of raw milk products by household members is a common risk factor for brucellosis outbreak among family members (Celebi et al., 2007). Independent risk factors for brucellosis found were younger age, male gender, profession and contact with animals and consumption of contaminated fresh cheese. Brucellosis were more prevalent in rural areas associated with cheese consumption (Asencio et al., 2014). Rates of Brucella in human in the province that makes cheese with raw milk is the double as that use pasteurized milk (Celebi et al., 2013). This may be due to the lack of appropriate education of the public regarding the risks associated with raw, nonheat treated cheese consumption (Karagiannis et al., 2012).

Likewise, distribution of brucellosis, as one of the most common zoonosis in the world, has changed in recent years due to socioeconomic factors and international travel. Brucellosis should be considered as a differential diagnosis of fever of unknown origin even in countries where it is not endemic; it is necessary not only to rule out travels to endemic regions through clinical history, but also the consumption of infected foods imported from such areas (Farina et al., 2008). B. melitensis outbreaks due to consumption of cheese made from unpasteurized milk were recorded all over the world, In London (Galbraith et al., 1969), In Houston, USA (Thapar and Young, 1986), In Argentine (Wallach et al., 1997), In Spain (Mendez Martinez et al., 2003), In Greece (Minas et al., 2007 and Karagiannis et al., 2012), and In France (Mailles et al., 2012).

There is an increasing interest in applying natural antimicrobial compounds in the food industry as consumers are increasingly avoiding the consumption of foods treated with chemicals. Natural alternatives are needed to achieve a high level of safety with respect to foodborne pathogenic microorganisms (Rauha et al., 2000). Organic acids offer several advantages as antimicrobials because they are generally recognized as safe (GRAS), have no limited acceptable daily intake, are low-cost, easy to manipulate, and effect minor sensory changes on the product. However, it is important to use these acids according to good manufacture practices in order to avoid the development of strains resistant to acidic conditions (Mani-López et al., 2012).

Organic acids such as citric and acetic acids have been used for years for decontamination of bacteria on beef, pork, and poultry (Mani-Lopez et al., 2012). Using of lemon cheese as alternative method for home traditional method without affecting the traditional taste. Juice or vinegar in food (as salads) provide a harsh environment for foodborne pathogens to survive because of the acetic or citric acids (Beuchat et al., 2006). Also, El-Khawas and Hassaan
(2015) indicate that adding of acetic acid (vinegar) to milk in the rate of $1 \%$ or citric acid $3 \%$ are effective antimicrobial intervention for kariesh cheese making. Given the significant microbial reductions observed it is an attractive and effective alternative for traditional process.

A very diffident obstacle in studying the survival of pathogenic bacteria under practical conditions in commercial cheese is the striving effort put forth for attaining cheese known to be infected with the bacteria under inspection. Generally, it is impossible under commercial conditions to predict in advance that the milk is infected with brucella and to determine the extent of the contamination that naturally occurs in the milk. Under such circumstances, it is recommended under laboratory conditions to workout artificially fortify milk then manufacture this milk into cheese.

Therefore, the aim of this study was designed to investigate the effect of citric and acetic acids (from natural sources) on Brucella species during manufacturing of kariesh cheese made from artificially fortified milk as alternative to the longstanding conventional home method without affecting the traditional customary taste.

\section{MATERIALS and METHODS}

Cow's skimmed milk was divided into 5 groups; the first (control for sensory analysis) was used for making of kariesh cheese as described by Fahmi (1950). Milk was pasteurized at $80^{\circ} \mathrm{C}$ for $15 \mathrm{~s}$, thereafter cooled to $40^{\circ} \mathrm{C}$ then inoculated with $3 \%$ $(\mathrm{v} / \mathrm{v})$ of yoghurt starter culture. The other 4 groups, were used for making kariesh cheese by adding citric acid (Merck) (1.5\% and 2\%) and vinegar (as acetic acid $1 \%$ and $1.5 \%$ ) as final concentration. Each one of the four groups were divided into 5 subgroup, each subgroup was inoculated with freshly grown culture of Brucella strain. While adding of acids, milk was shaken. All treatments were incubated at $37^{\circ} \mathrm{C}$ up to curding (about 2-3 hours). Salt at $1 \%$ was added between cheese layers and the curd was left to whey drain into small cheese molds at room temperature overnight. For consistency of results three replications were performed.

Sensory analyses: Organoleptic evaluation was carried out according to the scheme of Bodyfelt and Potter (2009). The sensory attributes evaluated were the flavour (1-10 points), body and texture (1-5 points) and appearance and colour (1-5 points).

Bacterial strains: Brucella melitensis biovar 3 field strain (B. mel. Field), B. melitensis biovar 3 Ether reference strain (B. mel. Ether), B. abortus biovar1 strain 544 reference strain (B. ab. 544), B. abortus S19 vaccinal strain (B. ab. S19) and B. abortus biovar1 field strain (B. ab. Field). All these strains 
were attained from the Department of Brucellosis, Animal Health Research Institute, Dokki, Giza, Egypt.

Culture preparation: Cultures were activated with two successive passes in $9 \mathrm{ml}$ of tryptic soy broth (TSB) (Oxoid) and incubated at $37^{\circ} \mathrm{C}$ for 3 days. Cultures of B. ab. 544 and B. ab. Field strains were incubated in $5 \% \mathrm{CO}_{2}$ atmosphere as these strains are $\mathrm{CO}_{2}$ dependent Brucellae. For each individual strain, $1 \mathrm{ml}$ of the stock inoculum was added to $100 \mathrm{ml}$ of TSB and incubated with shaking at $37^{\circ} \mathrm{C}$ for $18-24 \mathrm{~h}$ to reach a final concentration of approximately $10^{8}$ $\mathrm{CFU} / \mathrm{ml}$ (determined by McFarland standard). The stock inoculum was added to milk to give final concentration of approximately $10^{6} \mathrm{CFU} / \mathrm{ml}$. The inoculated milk was serially diluted and plated on tryptone soya agar media supplemented with antibiotic supplement (Oxoid) in duplicate to determine the initial count before treatment with the organic acids.

Bacterial count in cheese: For enumeration of Brucella organisms in cheese for each treatment, $25 \mathrm{~g}$ of cheese were placed in a stomacher bag with $225 \mathrm{ml}$ of $0.1 \%$ peptone water and stomached for $1 \mathrm{~min}$. Serial ten-fold dilutions were made in such a way that one or more dilutions when plated on solid medium produce a countable number of colonies and $0.1 \mathrm{ml}$ of the suspension of each treatment dilutions were plated on duplicate on Brucella selective medium (tryptone soya agar media supplemented with antibiotic supplement (Oxoid)) and incubated at $37^{\circ} \mathrm{C}$ either in air or in $5-10 \% \mathrm{CO}_{2}$ atmosphere according to the type of strain. Colonies were enumerated, and the $\mathrm{CFU} / \mathrm{g}$ for each treatment was determined. Sample plates were kept in incubation for at least 2 weeks before ruling out.

Furtherly cheese samples in which bacterial count was less than the detection limit (Negative plates), attempts for isolation of the inoculated strain were tried as the remaining portion of each cheese was emulsified in the least amount of peptone water and all the suspension was inoculated on medium plates and incubated in appropriate conditions as previously stated. Multiple plates were used to insure accuracy and maximum opportunity for isolation of Brucella organisms exist if any.

Statistical analysis: A completely randomized design was selected. The experiment was conducted in three repetitions. Data were analyzed by using the mixed procedure from SPSS software (release 20, IBM CO) after logarithmic transformation for bacteriological count. Means were separated by Fisher's least significant difference test, and significance was tested at $\alpha=0.05$.

\section{RESULTS}

Table 1: Sensory evaluation scores of kariesh cheese with different treatments.

\begin{tabular}{ccccc}
\hline Cheese treatments & $\begin{array}{c}\text { Flavor } \\
(1-10 \text { points })\end{array}$ & $\begin{array}{c}\text { Body and texture } \\
(1-5 \text { points })\end{array}$ & $\begin{array}{c}\text { Appearance and color } \\
(1-5 \text { points })\end{array}$ & $\begin{array}{c}\text { Total } \\
(20 \text { points })\end{array}$ \\
\hline Control & $10^{\mathrm{a}}$ & $4.9^{\mathrm{a}}$ & $4.7^{\mathrm{a}}$ & $19.6^{\mathrm{a}}$ \\
\hline Citric $1.5 \%$ & $9.8^{\mathrm{a}}$ & $4.8^{\mathrm{a}}$ & $4.8^{\mathrm{a}}$ & $19.4^{\mathrm{a}}$ \\
\hline Citric $2 \%$ & $7.5^{\mathrm{b}}$ & $3.2^{\mathrm{b}}$ & $3.3^{\mathrm{b}}$ & $14^{\mathrm{b}}$ \\
\hline Acetic $1 \%$ & $9.8^{\mathrm{a}}$ & $4.9^{\mathrm{a}}$ & $4.8^{\mathrm{a}}$ & $19.5^{\mathrm{a}}$ \\
\hline Acetic $1.5 \%$ & $9.6^{\mathrm{a}}$ & $4.7^{\mathrm{a}}$ & $4.5^{\mathrm{a}}$ & $18.8^{\mathrm{a}}$ \\
\hline
\end{tabular}

Means having different letters are significantly differ $(\mathrm{P}<0.01)$

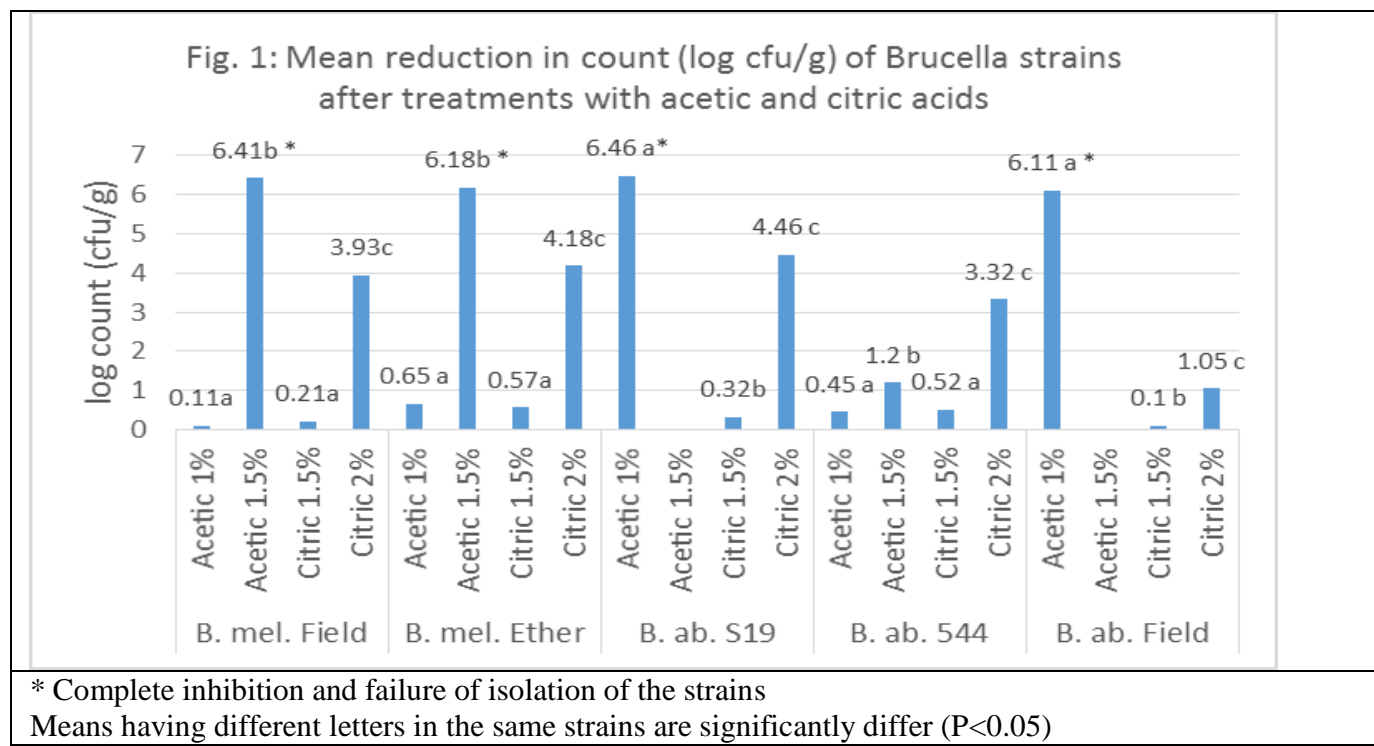


Concerning the yield, in previous study (El-Khawas and Hassan, 2015) there was no significant difference $(\mathrm{P}>0.05)$ between the yield between control and citric acid treatments. On the contrary, acetic acid treatments were significantly $(\mathrm{P}<0.01)$ the lowest. For sensory characteristics control, the citric acid (1.5\%) and the acetic acid (1\% and $1.5 \%)$ were more accepted $(\mathrm{P}<0.01)$ by the test panel (flavor and creamy body and texture) as compared with that made by the citric acid (2\%), which characterized by lemon flavor, crudeness body and texture and less whiter color than other treatments (Table, 1).

Fig. (1) represents the reduction in counts of Brucella strains for different treatments during manufacturing of kariesh cheese. Both strains of B. meletensis (ether and field) didn't affected by treatment with acetic acid $1 \%$ and citric acid $1.5 \%$ meanwhile, both of them were completely inhibited (failed to be isolated) by treatments with acetic acid $1.5 \%$, and citric acid $2 \%$ reduced the count by about $4 \log \mathrm{cfu} / \mathrm{g}$.

Whatever, Both of B. abortus field strain and $B$. abortus S19 vaccinal strain were completely inhibited (failed to be isolated) by treatment with $1 \%$ acetic acid, B. abortus 544 strain didn't affect by this concentration and was reduced to lesser extent $(1.2$ $\log \mathrm{cfu} / \mathrm{g}$ ) by $1.5 \%$ acetic acid. Citric acid $2 \%$ significantly $(\mathrm{P}<0.05)$ reduced the count of B. abortus S19 strain (4.46 log cfu/g) and B. abortus 544 strain (3.32 log cfu/g) and to a lesser extent B. abortus field strain $(1.05 \log \mathrm{cfu} / \mathrm{g})$.

Although all strains were significantly $(\mathrm{P}<0.05)$ affected by treatment with acetic acid, B. abortus 544 strain was the more resistant strain. On the other hand, all strains were significantly $(\mathrm{P}>0.05)$ resistant to $1.5 \%$ citric acid, but treatment with $2 \%$ citric acid significantly $(\mathrm{P}<0.05)$ reduced the count of all strains, nevertheless $B$. abortus field strain was the more resistant strain.

\section{DISCUSSION}

Significant proportion of cheeses in Egypt are made from raw milk due to the desired flavor and aroma of cheese which much more favorable in raw milk cheeses than in the ones made from pasteurized milk. Due to the immense demand nowadays on such type of food, producing cheese from raw milk has resuscitate again. Cheeses made from raw milk are in the category of the dangerous food in recent years (West, 2008). Despite the in-adequate hygienic quality used in processing such kind of raw milk processed cheese, yet remains widespread.

Sensory properties: Gobbetti et al. (1998) remind that the flavour intensity score of cheese was probably due to the combination of the higher concentration of lactic, citric and acetic acids and free amino acids and soluble peptides. Very few sensory differences between the control samples and the treated samples were detected by a consumer panel. Thus, acetic and citric acids treatments in the used concentrations did not cause serious adverse sensory changes. Use of these antimicrobial treatments can be a promising intervention (Harris et al., 2006).

\section{Bacteriological analysis:}

Although kariesh cheese is a good source of nutritive materials, there is a risk of contracting brucelosis due to consumption of non-pasteurized dairy products, when these are not subjected to the normal sanitary and health controls (Castell Monsalve et al. 1996). Meanwhile, the survival of Brucella strains in different dairy products is inversely proportional to the $\mathrm{pH}$ (El-Daher et al., 1990 and Estrada et al., 2005), these strains continue to increase due to elevated temperature during curdling. MendezGonzalez et al. (2011) and Santiago-Rodriguez Mdel et al. (2015) recovered B. melitensis and B. abortus at $\mathrm{pH} 4$ and $\mathrm{a}_{\mathrm{w}} 0.89$ in significantly high count in cheese elaborated with raw milk and ripened at $24^{\circ} \mathrm{C}$. Nearly most previous researches studied the effect of $\mathrm{pH}$ on brucella organisms and they stated that $\mathrm{pH}$ of the product plays a critical role in the survival and growth of Brucella spp. in dairy products. The authors suggested a direct correlation between the survival of the microorganism and the $\mathrm{pH}$ and to argue as well that the role of dairy products as a vehicle for transmitting several pathogens could be predicted by determining the $\mathrm{pH}$ values of the products (Davies and Casey, 1973; Eloy and Lacrosse, 1976; Northold, 1984 and El-Daher et al., 1990).

Organic acids are considered weak acids meaning the antimicrobial effect of organic acids is mainly caused by its undissociated forms (Malicki et al., 2004). They passively diffuse through the bacteria cell wall and internalizing into neutral $\mathrm{pH}$ dissociating into anions and protons. Release of the protons causes the internal $\mathrm{pH}$ to decrease which exert inhibitory effects on the bacteria (Ricke, 2003). Moreover, the pH at which the acid is half dissociated (pKa) of citric and acetic acids varies between 3 and 4 (Dibner and Buttin, 2002) which is near to $\mathrm{pH}$ of cheese making (4.6).

Likewise, rapid acidification in the early stages of the process of raw milk cheeses manufacture is a key factor to effectively control the development of pathogens with low core contamination in raw-milk (Millet et al., 2006).

In comparison between acetic and citric acids in the same concentration, acetic acid was more effective than citric acid, the result which agree with that obtained by Seoknam et al. (2003) and El-Khawas and Hassan (2015). Difference between the effect of acetic and citric acids may be referred to that, lethal 
effects of these weak acids depend on concentration, $\mathrm{pH}$ of the environment and the dissociation constant of each acid beside adapted or resistant strains due to sub-lethal conditions (Foster and Hall, 1990). Acetic acid is widely used as preservative substances and $\mathrm{pH}$-adjusting ingredients in various foods. As preservatives, acetic acid gain their antimicrobial effect by lowering the $\mathrm{pH}$-value below the growth range, and their undissociated forms of acid inhibit the metabolic mechanisms of organisms (Jay, 1978).

The attained results assures the serviceable advantageous and usable outcomes of the study and the beneficial influences on the public although the resistance of field strains of $B$. abortus, as this organism die much more rapidly in commercial cheese than in the fortified laboratory samples. This could be attributed to the great influence of some factors, such as bacteriocins, hydrogen peroxide, volatile compounds, and other metabolites produced by lactic acid bacteria which possess an inhibitory effect on the growth of pathogens (Northold, 1984 and Ming, et al., 1989). Also, extraction of cream layer before manufacturing of cheese may wane the probability of contracting brucellosis as huge number of the organism is removed with fat globules to which the Brucella microorganisms adhered (Hamdy and Abdel-Hakiem, 1994).

\section{CONCLUSION}

Results of this study indicated that adding of vinegar to milk in the rate of $1.5 \%$ or citric acid $2 \%$ are effective antimicrobial intervention for kariesh cheese making that could control most of Brucella strains, while retain the favorable sensory properties of traditional non-heat treated product. Given the significant microbial reductions observed it is an attractive and effective alternative for traditional process.

\section{REFERENCES}

Alim, A. and Tomul, Z.D. (2005): Short communication: Investigation of Brucella in the fresh cheese samples sold at the bazaars of district in Sivas Center, Turkey. Mikrobiyol. Bul. 39: 219-23.

Altekruse, S.F.; Timbo, B.B.; Mowbray, J.C.; Bean, N.H. and Potter, M.E. (1998): Cheeseassociated outbreaks of human illness in the United States, 1973 to 1992: Sanitary manufacturing practices protect consumers. J Food Prot. 61: 1405-7.

Asencio, M.A.; Herraez, O.; Maria Tenias, J.; Garduno, E.; Huertas, M.; Carranza, R. and Mauro Ramos, J. (2014): Seroprevalence survey of zoonoses in Extremadura, southwestern Spain, 2002-2003. Jpn. J. Infect. Dis. 68(2): 106-12.

Beuchat, L.R.; Ryu, J.H.; Adler, B.B. and Harrison, M.D. (2006): Death of Salmonella, Escherichia coli O157:H7, and Listeria monocytogenes in shelf-stable, dairy based, pourable salad dressings. J. Food Prot., 69: 801-814.

Bodyfelt, F. and Potter, D. (2009): Creamed cottage cheese. In: Clark, S.; Costello, M. Drake, and M. Bodyfelt, F. (Eds.). The Sensory Evaluation of Dairy Products. $2^{\text {nd }}$. Springer Sci. Business Media, LLC, New York. USA. pp.: 167-190.

Castell Monsalve, J.; Rullan, J.V.; Peiro Callizo, E.F. and Nieto-Sandoval Alcolea, A. (1996): Epidemic outbreak of 81 cases of brucellosis following the consumption of fresh cheese without pasteurization. Rev. Esp. Salud Publica, 70: 303-11.

Celebi, G.; Kulah, C.; Kilic, S. and Ustundag, G. (2007): Asymptomatic Brucella bacteraemia and isolation of Brucella melitensis biovar 3 from human breast milk. Scand. J. Infect. Dis. 39: 205-8.

Celebi, O.; Celebi, D. and Eda Balkan, C. (2013): Effects of boiling dairy products on human brucellosis. Eurasian J. Med. 45: 73-6.

Davies, G.D. and Casey, A. (1973): The survival of Brucella abortus in milk and milk products. Brit. Vet. J. 129: 345-353.

Dibner, J.J. and Buttin, P. (2002): Use of organic acids as a model to study the impact of gut microflora on nutrition and metabolism. J. Appl. Poultry Res.; 11: 453-463.

El-Daher, N.; Na'was, T. and Al-Qaderi, S. (1990): The effect of the $\mathrm{pH}$ of various dairy products on the survival and growth of Brucella melitensis. Ann. Trop. Med. Parasitol, 84: 523-8.

El-Khawas, K.M. and Hassaan, H.M. (2015): Control of food poisoning bacteria during manufacturing of acid cheese using some organic acids. Assiut Vet. Med. J. 61 (145): 40-46.

Eloy, C. and Lacrosse, R. (1976): Composition d'un milieu de culture destine a effectuer de denombrement des micro-organismes thermophiles du yoghourt. Bull. Rech. Agron. Gemblou. 11: 83-86.

Estrada, Z.A.; Mota de la Garza, L.; Sanchez Mendoza, M.; Santos Lopez, E.M.; Filardo Kerstupp, S. and Lopez Merino, A. (2005): Survival of Brucella abortus in milk fermented with a yoghurt starter culture. Revista latinoamericana de Microbiología, 47: 88-91.

Fahmi, A.H. (1950): Studies on Kareish cheese. Ph.D. Thesis, Reading University, Reading, England. 
Farina, F.; Fuser, R.; Rossi, M. and Scotton, P.G. (2008): Brucellosis outbreak in Treviso province caused by infected cheese from an endemic area. Infez. Med. 16: 154-7.

Foster, J.W. and Hall, H.K. (1990): Adaptive acidification tolerance response of Salmonella Typhimurium. J. Bacteriol., 172: 771-778.

Francois, Z.N.; Ahmed, N.; Félicité, M.T. and ElSoda, M. (2004): Effect of ropy and capsular exopolysaccharides producing strain of Lactobacillus plantarum $162 \mathrm{RM}$ on characteristics and functionality of fermented milk and soft Kareish type cheese. African J. Biotechnology., 3: 512-518.

Galbraith, N.S.; Ross, M.S.; De Mowbray, R.R. and Payne, D.J. (1969): Outbreak of Brucella melitensis type 2 infection in London. $\mathrm{Br}$. Med. J. 1: 612-4.

Gobbetti, M.; Carsetti, A.; Smacchi, E.; Zocchetti, A. and De Angelis, M. (1998): Production of Crescenza cheese by incorporation of bifido bacteria. J. Dairy Sci., 81: 37-47.

Hamdy, M.E. and Abdel-Hakiem, E.H. (1994): Viability of Brucella melitensis in artificially infected cream. Assiut Vet. Med. J. 31 (61): 175-181.

Harris, K.; Miller, M.F.; Loneragan, G.H. and Brashears, M.M. (2006): Validation of the use of organic acids and acidified sodium chlorite to reduce Escherichia coli 0157 and Salmonella Typhimurium in beef trim and ground beef in a simulated processing environment. J. Food Prot., 69: 1802-1807.

Hofi, M. (2011): Contamination in dairy chains and approaches to quality control in Egypt. Internet J. Food Safety, 13: 264-269.

Jay, J.M. (1978): Food Preservation by the Use of Chemicals. Modern Food Microbiology. $2^{\text {nd }}$ ed. D. Van Nostrand Company, New York, 176-177.

Karagiannis, I.; Mellou, K.; Gkolfinopoulou, K.; Dougas, G.; Theocharopoulos, G.; Vourvidis, D.; Ellinas, D.; Sotolidou, M.; Papadimitriou, T. and Vorou, R. (2012): Outbreak investigation of brucellosis in Thassos, Greece, 2008. Euro Surveill. 17(11): 20116

Kasimoglu, A. (2002): Determination of Brucella spp. in raw milk and Turkish white cheese in Kirikkale. Dtsch Tierarztl Wochenschr, 109: 324-6.

Lusk, T.S.; Strain, E. and Kase, J.A. (2013): Comparison of six commercial DNA extraction kits for detection of Brucella neotomae in Mexican and Central Americanstyle cheese and other milk products. Food Microbiol. 34: 100-5.

Mailles, A.; Rautureau, S.; Le Horgne, J.M.; PoignetLeroux, B.; D'arnoux, C.; Dennetiere, G.; Faure, M.; Lavigne, J.P.; Bru, J.P. and GarinBastuji, B. (2012): Re-emergence of brucellosis in cattle in France and risk for human health. Euro Surveill. 17 (30): 20227.

Malicki, A.; Zawadzki, W.; Bruzewicz, S.; Graczyk, S. and Czerski, A. (2004): Effect of formic and propionic acid mixture on Escherichia coli in fish meal stored at $12^{\circ} \mathrm{C}$. Pak J. Nutr., 3: 353-356.

Mani-López, E.; García, H.S. and López-Malo, A. (2012): Organic acids as antimicrobials to control Salmonella in meat and poultry products. Food Res. Intern., 45: 713-721.

Mendez-Gonzalez, K.Y.; Hernandez-Castro, R.; Carrillo-Casas, E.M.; Monroy, J.F.; LopezMerino, A. and Suarez-Guemes, F. (2011): Brucella melitensis survival during manufacture of ripened goat cheese at two temperatures. Foodborne Pathog. Dis. 8: 1257-61.

Mendez-Martinez, C.; Paez Jimenez, A.; CortesBlanco, M.; Salmoral Chamizo, E.; Mohedano Mohedano, E.; Plata, C.; Varo Baena, A. and Martiinez Navarro, F. (2003): Brucellosis outbreak due to unpasteurized raw goat cheese in Andalucia (Spain), January - March 2002. Euro. Surveill. 8: 164-8.

Millet, L.; Saubusse, M.; Didienne, R.; Tessier, L. and Montel, M.C. (2006): Control of Listeria monocytogenes in raw-milk cheeses. Inter. J. Food Microbiol. 108: 105-114.

Minas, M.; Minas, A.; Gourgulianis, K. and Stournara, A. (2007): Epidemiological and clinical aspects of human brucellosis in Central Greece. Jpn. J. Infect. Dis. 60: 362-6.

Ming, X.; Ayres, J.W. and Sandine, W.E. (1989): Effect of yoghurt bacteria on enteric pathogens. pp 161-176. In: Live Active Yoghurt: Nutritional and Health Properties ed. Chandan, R.C. Proc. Int. Yoghurt Conf. N.Y.

Northold, M.D. (1984): Growth and inactivation of pathogenic microorganisms during manufacture and storage of fermented dairy products. A review. Neth. Milk. Dairy J. 38: 135-150.

Ongor, H.; Cetinkaya, B.; Karahan, M. and Bulut, H. (2006): Evaluation of immunomagnetic separation-polymerase chain reaction in direct detection of Brucella abortus and Brucella melitensis from cheese samples. Foodborne Pathog. Dis. 3: 245-50.

Palmer, S.R.; Soulsby, L. and Simpson, D.I.H. (1998): Zoonoses. Oxford University Press. pp. 22-23.

Rauha, P.; Remes, S.; Heinonen, M.; Hopia, A.; Kahkonen, M. (2000): Antimicrobial effect of Finnish plant extracts containing flavonoids and other phenolic compounds. Int. J. Food Microbiol. 56: 3-12.

Reps, A.; Drychowski, L.J.; Tomasik, J. and Niewska, $K . W$. (2002): Natamycin in ripening cheeses. Pakistan J. Nutrition, 1(5): 243-247. 
Ricke, S.C. (2003): Perspectives on the use of organic acids and short chain fatty acids as antimicrobials. Poultry Sci., 82: 632-639.

Santiago-Rodriguez Mdel, R.; Diaz-Aparicio, E.; Arellano-Reynoso, B.; Garcia-Lobo, J.M.; Gimeno, M.; Palomares-Resendiz, E.G. and Hernandez-Castro, R. (2015): Survival of Brucella abortus aqpX Mutant in Fresh and Ripened Cheeses. Foodborne Pathog. Dis. 12: 170-5.

Seleem, M.N.; Boyle, S.M. and Sriranganathan, N. (2010): Brucellosis; A reemerging zoonosis Vet. Microbiol., 140: 392-398.

Seoknam, K.; Aera, J.; Sang, O.L.; Joong, S.M.; Il, S.K. and Mooha, L. (2003): Effect of organic acids on microbial populations and Salmonella
Typhimurium in pork loins. AsianAustralasian J. Animal Science, 16 (1): 96-99

Thapar, M.K. and Young, E.J. (1986): Urban outbreak of goat cheese brucellosis. Pediatr. Infect. Dis. 5: 640-3.

Wallach, J.C.; Samartino, L.E.; Efron, A. and Baldi, P.C. (1997): Human infection by Brucella melitensis: An outbreak attributed to contact with infected goats. FEMS Immunol. Med. Microbiol. 19: 315-21.

West, H.G. (2008): Food fears and raw-milk cheese. Appetite, 51: pp. 25-29.

Young, E.J. and Suvannoparrat, U. (1975): Brucellosis outbreak attributed to ingestion of unpasteurized goat cheese. Arch. Intern. Med. 135: $240-3$.

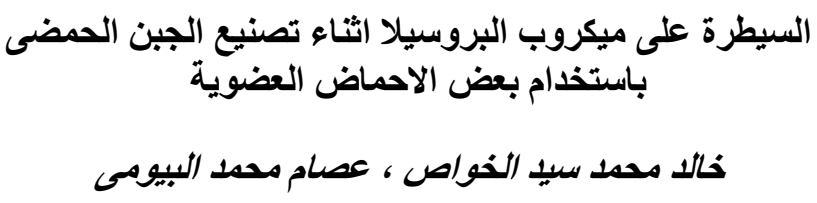

Email: kkhwas@yahoo.com

Assiut University web-site: www.aun.edu.eg

الجبن القريش جبن حمضى طرى وبالرغم من قيمته الغذائية العالية إلا انه يصنع عادة فى المنازل من لبن خام مما يجعله مصدرا

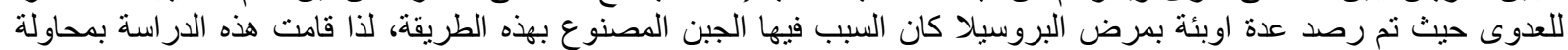

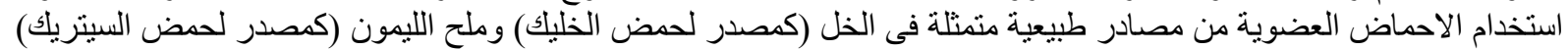

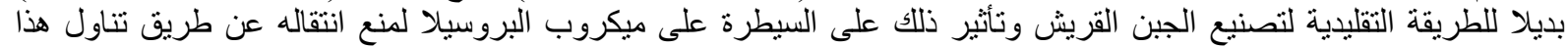

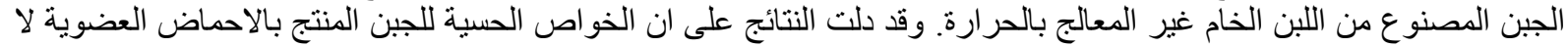

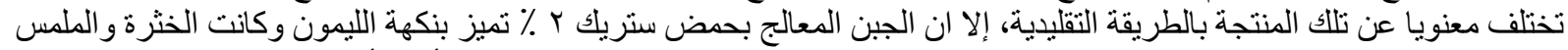

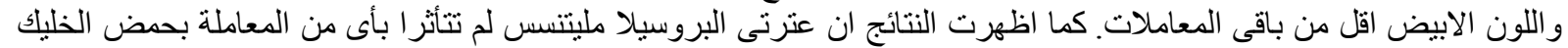

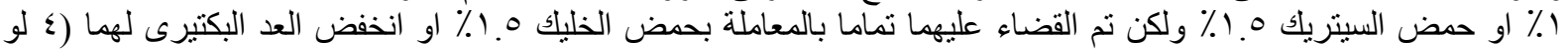

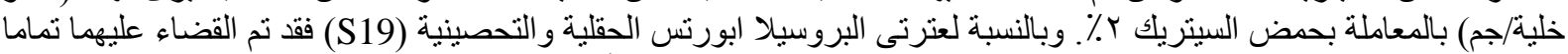

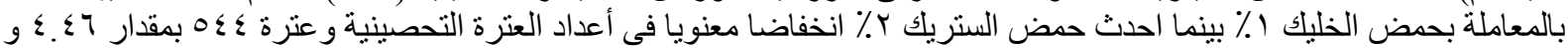

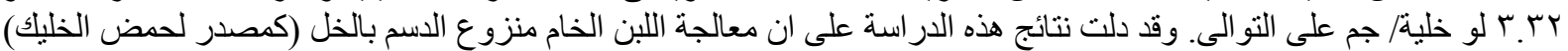

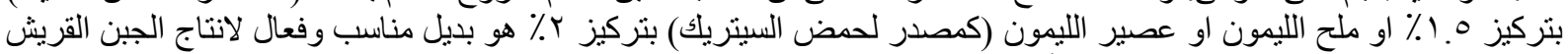
و السيطرة على ميكروب البروسيلا بدون التأثثر على الطعم المميز له له الكلمات الدالة: الجبن القريش ، البروسيلا ، الاحماض العضوية ، الخل ، الليمون 